\title{
Exploring the Availability, Accessibility and Adequacy of the National Students' Financial Aid Scheme: A Case Study
}

\author{
Dr Thulani E Mhlongo, PhD \\ University of Johannesburg \\ South African Council of Educators \\ South Africa
}

\begin{abstract}
Research findings revealed that the provision of education and training to all citizens is fundamental to the success of any government's overall strategy. For this to occur, strategies are being evolved globally to make scholarship schemes available to disadvantaged students. In South Africa, the National Student Financial Aid Scheme (NSFAS) is one such program which assists such students with tertiary education requirements. Unfortunately, very few studies have been conducted on the availability, accessibility and adequacy of such programs. This report presents the findings of a quantitative research project that was conducted among NSFAS Loan recipients at North-West University (Mafikeng Campus). Permission was sought from the Dean of Students and a total of 83 students were randomly selected from a list of current loan recipients. The sample frame was obtained from the Student Academic Services. The existing AMA Student Loans Questionnaire was utilized in the survey. Cross-tabulations were performed on several variables to assess whether or not any relationships existed between them. A Chi-square test was subsequently applied to ascertain if any of the relationships were statistically significant or not. The findings suggest that, the NSFAS is not easily available, accessible, or adequate. Among the student recommendations for improving the availability of, accessibility to and marketing awareness of the NSFAS, it was by 26 respondents (26.5\%) that NSFAS should improve awareness in Secondary Schools of the funding available, in that it might offer needy individuals who previously believed that they had no future and opportunity to improve their lives. A further six respondents (7.2\%) indicated that NSFAS should advertise their financial aid scheme more widely on university campuses. Two respondents (2.4\%) stated that NSFAS should also provide financial assistance for transport, accommodation and recreational activities.
\end{abstract}

Keywords: Availability, Accessibility, Adequacy, and National Students Financial Aid Scheme

\section{Introduction and rationale}

In 1994, apartheid was abolished in South Africa and the newly introduced democracy presented new opportunities such as equal rights to the access of financial resources (Hoogeveen \& Ozler, 2004:2). However, even though South Africa can now be classified as an upper-middle-income country as per capita, most South African households experience absolute poverty with 50\% of the population earning less than R352.53 per month (Carter \& May, 1999:2). The distribution of earnings in South Africa has always been directly linked to the disparity of access to higher education (Bhorat, Leibbrandt, Maziya, Van Der Berg, \& Woolard, 2001:29).The next step would involve the attempt to alleviate this situation of disparity through the use of development programs, funded both nationally and internationally. One of these projects focuses attention on the improvement and progression of higher education, its rationale being that investment in education is critical for economic growth, social progress and the improvement of health care and may therefore be a crucial step in poverty alleviation (Bhorat \& Van Der Westhuizen, 2009:12).

However, in many countries worldwide (including South Africa), it is proving increasingly difficult for public resources to finance tertiary education. Therefore, a cost-sharing between the students and the government is rapidly becoming the norm (Salmi, 2003:1). The scholar, Salmi (2003:2), further stressed that although costsharing could be effective, it could not be equitably executed without sufficient student support mechanisms for academically eligible but needy students. As early as 1993 Barr pointed out two means of offering financial support to disadvantaged students, namely; student loan programs and targeted scholarship schemes, which made finances available to those who desperately needed it (Barr, 1993:719). 
Although the NSFAS is seen as one such project, assisting disadvantaged students through tertiary education, it has been noted that paucity of studies exists on the availability, accessibility and effectiveness of such programs.

\section{Research question}

The crucial question is, to what extent is the National Student Financial Aid available, accessible and adequate in alleviating the needs and expectations of current study loan recipients at the North -West University (Mafikeng Campus) in particular?

\section{Aim of the report}

The broad aim is to report on the findings of a research project that was conducted to assess the availability, accessibility and adequacy of the National Student Financial Aid Scheme at North-West University (NWU) in order to profile the expectations, needs and frustrations of current loan recipients.

\section{Significance of the report}

One of the major contributions of this report is that it may highlight the experiences and perceptions of NSFAS recipients about the student loan scheme. Secondly, it is envisaged that the report may enlighten recipients to make constructive recommendations that could, contribute to the effectiveness of student loan and/or bursary funds both locally and globally.

\section{Research design and methodology}

A quantitative research paradigm was utilized as the method to gather data and to assess the research statement as it required a larger sample than that of a qualitative approach (Maree, 2007:56). This approach was applied through the use of a non-experimental, correlation research design.

\section{Population and sampling}

The study was conducted among current NSFAS loan holders at NWU. The Dean of Student Affairs provided his support for the research project, and a total of 83 students were randomly selected from the sample frame - a list of current loan recipients at NWU. The sample frame was obtained from the Student Academic Services. Within the list provided, every $28^{\text {th }}$ individual was selected and telephonically contacted to arrange a suitable time to meet with the researcher and answer a standardized questionnaire. Three times on three separate days were provided in order to accommodate any constraints imposed students` timetables.

\section{Measuring instruments}

The existing AMA Student Loans Questionnaire was utilized in this survey.

\section{Ethical considerations}

The following safeguards suggested by Cohen, Manion and Morriso (2007: 52) were strictly adhered in order to protect the anonymity of the respondents: Only the chief researcher had access to the original sampling frame. He was also responsible for drawing the sample and replacing the names with codes. The assistant researchers only had access to the codes and applicable contact numbers. Once the sample was drawn, the potential respondents were contacted, in order to seek informed consent. In addition, the following principles were strictly adhered to: voluntary participation; the principle of anonymity; the provision of the research objectives, articulated in writing and a description of how the data would be employed. Furthermore, the co-researchers were trained on ethics in social research and made aware of any potential ethical concerns that might be evoked by this study.

\section{Literature review regarding how the NSFAS is administered both locally and globally}

Financial aid plays a major role in the development and growth of a society. Any increase in the number of individuals completing their tertiary education, leads to the labor market flourishing. Another important factor contributing to the end of financial aid is the ever increasing expenses associated with tertiary institutions. Furthermore, financial aid can be found globally in various forms. Within South Africa however, a major form of financial aid is the National Student Financial Aid Scheme, which aims to equate access to tertiary education. In this section a detailed discussion on financial aid available globally, and more specifically within South Africa. The challenges and knowledge base, as well as academic retention will also be discussed in detail.

\section{Student Enrolment and Retention Theories}

Kerkvliet and Nowell (2005: 86) indicated that a test of retention theories by researchers centres on three factors. Firstly, students who are not prepared for further education and those who come from very impoverished backgrounds, run a high risk of dropping out of higher education institutions. 
Secondly, students will have to integrate both socially and academically, by recognizing social and institutional norms, including its academic goals and programs (Kerkvliet and Nowell, 2005: 86).According to these retention theories, it is essential to assist students to relate to the academic and social systems of institution, so as to enhance retention. In order to do so, many universities have embraced programs that are structured to advance both academic and social integration. These institutions also retain advisers to assist students to choose suitable academic paths and make academic decisions (Kerkvliet and Nowell, 2005: 86).The third factor in retention is financial aid. Researchers indicate that retention can be reduced by moderating educational cost (Kerkvliet\& Nowell, 2005:86).However, the consequences that financial aid has on retention are unclear.

In many developed and developing nations, institutions have been put under pressure by the national plan for higher education to increase the number of student enrollments in order to produce the skilled labuor needed for the labor market and economy. In South Africa, this resulted in a $25 \%$ increase in student enrollment figures at higher education institutions (Koen, Cele \& Libhaber, 2006: 405). A major concern in South Africa is that disadvantaged students lack the ability to survive academically and that their finances will not adequately fund their tertiary education. Many of these students have incurred huge debts, due to their inability to pay tuition, coupled with ever increasing tuition fees (Koen, et al., 2006:405). Consequently, this has resulted in high rates of student withdrawal from higher education institutions, which subsequently has an impact on student retention. According to Ben-Tsur (2007: 319), various factors relating to student retention include, a student's personality and as the effect that their environment has on his or her obligation to study and to the higher education institution itself. All of these elements combined generate the levels of student amalgamation that, in turn, affect student's perseverance and motivation. However, it should be noted that the crucial reason why students drop out of higher education institutions relates to financial difficulty. Although South Africa is rated as a country with a primary middle class income, the reality is that, due to the racial divide brought about by apartheid, Africans and coloured still live in poverty (Breier, 2010: 658). Thus, challenges such as highly competitive and stringent admission benchmarks in higher education institutions often prevented them from entering an institution and completing their education. Thomas et al. (2003: 33) stated that individuals most affected by these factors belong to minority racial or ethnic groups, immigrants, as well as disadvantaged students from poor backgrounds.

\section{Knowledge Base of Financial Aid for Higher Education}

Research findings suggest that potential students find it difficult to take out study loans, they lack of the collateral that is required by financial institutions. Thus, financial aid, in the form of grants or funding is designed to ease these restrictions (Booij, Leuven, \& Oosterbeek, 2011: 12).Unfortunately, in both the UK and US, many students who eligible for financial aid often do not make use of it. This is also the case in the Netherlands, where it has been found that only $35 \%$ of eligible students utilize student loans. Some researchers argued that the reason for this is that, the students are ignorant of the existence of the financial aid program .Another plausible reason is difficulty experienced by students in the application process, especially in the United States (Booij, et al., 2011: 11-12).

\section{The Essential Need of a Merit Based Financial Aid}

The disparity between the matriculation rates of low and high income student's has not only continued during the last 30 years, but has broadened, despite the resources spent on need-based financial aid. Consider the effect of income-targeted institutional aid programs that are focused on the matriculation model of low-income students, where institutional grants substitute student loans. These grants cover the costs of tuition, fees, and accommodation, and are essential in assisting individuals through higher education (Waddell \& Singell, 2011:203-204).

Although grants have been given to needy students, the escalating cost of university education and student debt continues to threaten the entry of low - income students into higher education. This may be due in part to financial aid programs not keeping up with the increasing costs of higher education (Waddell\& Singell, 2011: 204). As a result, federal governments have enforced policies in higher education that have given rise to need-and-merit based financial aid, with the aim of widespread admissions guidelines. These guidelines along with state subsidies have helped to maintain tuition that is below cost (Singell, 2002: 446). However, even with these subsidies, a number of individuals are still unable to independently pay their tuition fees. This has necessitated the implementation of financial aid scheme(s). 


\section{Looking Toward Financial Aid in a Global Perspective}

The dramatic reduction in government funding of higher education in various countries around the world has brought about a financial burden for these institutions. Consequently, higher institutions are motivated to tap into the market for financial assistance (De Villiers \& Steyn, 2006:35. The strategies that are presently being evolved by various developed and developing countries, in terms of provision of financial aid at higher institutions are briefly discussed below.

\section{Ghana}

In Ghana the government is responsible for matters relating to higher education. Hence, up until the 1980's higher education in Ghana was completely funded by the government, through grants made to institutions to cover students' tuition fees and accommodation, as well to develop and maintain the institutions infrastructure (Teffera \& Knight, 2007: 210).At the same time there has been an increase in the private provision of higher education which gave rise to the accreditation of approximately 32 institutions by the National Board, which is responsible for various degrees and diploma programs. Subsequently, during the 1980's, the massive surplus of students at university resulted in institutions being unable to maintain and provide sufficient tertiary educational services. As a result, the Ghanaian government began to look at cost sharing and recovery at the higher education level. Thus, due to a decrease in government funding, tertiary institutions began to roll out revenue generating policies by allowing the enrollment of foreign students and charging the full tuition fees (Teffera \& Knight, 2007:209- 211).

\section{China}

From as early as 1993, the government introduced subsidy for financially disadvantaged students. This was closely followed by a work-study program, introduced in 1994, and subsequently, a tuition discount in 1995 (Yang, 2009: 561). As a form of financial aid, the Chinese Ministry of Education and Ministry of Finance established a "Green Channel" which allowed financially disadvantaged students to graduate at tertiary education institutions, before having to pay for their tuition.

\section{Kenya, Tanzania and Uganda}

In Kenya, Tanzania and Uganda, a unique form of financial aid was established. This system requires a students to finance for his or her university education by taking out a government loan and pay it off as soon as he or she is gainfully employed (Zeleza \& Olukoshi, 2004: 87).Consequently, doors opened within the higher education sector, in where wealthy individuals made donations to a university budget, founded scholarships and bursaries, or subsidized tuition. These benefits have encourage students to dedicate themselves to their studies, and offered a means of enlarging the university or tertiary education sector. Unfortunately, this system has been misused by recipients who failed to pay back the money borrowed. As a result, Kenya implemented a system that could recover these loans. In this context, Chapman (2010: 688), stated that the loan repayment was determined by taking a percentage of the borrower's income during a period, assigned to overhaul a debt. Subsequently, in July 1995, Kenya established the Higher Education Loans Board, tasked with distributing bursaries, loans and scholarship to prospective Kenyan students (both locally and overseas). The board is further mandated to recover all of the loans taken out by students who are unable to pay. This system has functioned successfully for a number of years, and as a result, Tanzania and Uganda have begun working towards implementing similar arrangement, in order to improve the functioning and administration of their tertiary education spheres (Zeleza \& Olukoshi, 2004: 89).

\section{United States of America}

According to Goetz, Miti, Desai and Cude (2008:13), in the past few years, some of the US states implemented a merit-based scholarship program to sustain their higher education sphere. It aims to ascertain the difference in financial conducts between college students in Georgia who were awarded the merit-based Hope (Helping Outstanding Student Educationally) Scholarship, and other students who lost the right to use the scholarship, as a result of poor academic performance. Due to concurrent increase in the cost of college education and student debt level in the US, another issue that these states had to address was a prohibition on any additional information on the financial dealings of college students (Goetz, et al., 2008: 14).Between the academic year 2005 and 2006 the Hope scholarship program was available to undergraduate students at both public and private colleges and universities. Thereafter, 14 other states in the USA implemented similar merits-based scholarship programs (Goetz, et al., 2008:14).However, a survey has revealed that many students were "financially at- risk" amassing large amounts of debt as they abused credit after graduating from tertiary institutions(Lyons, 2004: 13). 
Along, with these findings, has been a rise in anxiety among university administrators, policy makers and educators that concerns college students` financial behaviors regarding credit card use and future loan repayments (Goetz, et al., 2008: 14).

\section{Great Britain}

In November 1979, following the announcement of the end to subsidies for foreign students in Great Britain, the government had to create a new framework for higher education. As a result, it cut public expenditure, including foreign student subsidies and institutional funding, resulting in an increase in student numbers and a five percent per year decrease school leaver numbers. There were 510000 to 670000 full time students enrolled between 1979 and 1989, 43\% of the polytechnics and colleges.( Williams, 1992: 2-3).Subsequently, during 1980 to 1981, higher education in the UK experienced a sizeable decrease in general and regular findings. This brought about a financial crisis, which consequently forced the government to encourage institutions to source their incomes from both government and non-government sources which they were openly held accountable for (Williams, 1992: 5).

\section{Australia}

In 1989 the Higher Education Country Scheme (HECS) was established in Australia, this replaced the old system from 1974, which had not charged students tuition fees. The rationale behind the HECS was to raise existing funds for higher education, so as to encourage growth, but without enforcing fees on students. The HECS requires that students pay back a fraction of the cost of their university education through taxation, as when their income rises above certain thresh holds. Thus, graduates with upper level earnings have an elevated rate of reimbursement compared to those who earn lesser amounts; the total pay - back is dependent upon income levels, which makes the HECS distinctive from graduate taxation (Marks, 2008:72- 73). One of the underlining principles of the HECS is that it decreases the cost to government of financing higher education. The HECS added; in 2002; \$1.8 billion or $16 \%$ of the total costs of higher education to make certain that people profited from a university education but also contributed to its cost. Since the HECS has been established in Australia, income conditional loan schemes have been initiated in other countries (Marks, 2008: 74).However, the HECS has been appraised as it adds to the socioeconomic inequalities in university education. For example, students from disadvantaged backgrounds are more likely to fall into debt, thereby not participating to as great a degree in higher education than students who come from wealthy backgrounds (Marks, 2008: 74).

\section{Netherlands}

Booij, et al. (2011: 3) reveals that in the Netherlands; the Dutch government has established a financial aid system that touches on upon three main areas concerning students. Firstly, grants that are suitable for all students. Secondly these accommodate students from low-income tiers. Thirdly, it is offered as a mortgage repayment financial aid scheme. Furthermore, all of these elements are controlled by a group established by the Netherland government. Applications for the aid scheme can be easily made online and prospective students are given brochures at high schools that explain what is complete an application.

\section{South Africa}

Prior to 1994 the policy of separatism created a poor society, especially of black people. Universities and technickons produced predominantly white graduates and an uneven figure of black graduates. Even individuals who were academically sound were often too poor to pay for their university fees without receiving extra financial support. This has been exacerbated by a sudden reduction in the public funding of higher education in various continents over the world. Consequently, institutions are driven to tap into the market for funding (De Villiers \& Steyn, 2006: 35). Moreover, according to De Villiers and Steyn (2006: 35), the success rate of securing such funding from philanthropic organizations, entrepreneurs and other financial organizations is not high. Therefore; in 1995; South Africa was compelled to initiate national student loan schemes to enable less privileged individuals to gain access to higher education (Zeleza \& Olukoshi, 2004: 84).Following the democratic elections in 1994 which resulted in the abolition of apartheid, the South African Government was urged to move towards poverty alleviation by introducing a sustainable financial aid scheme enabled less privileged students to gain access to tertiary education(De Villiers, 2009: 4).Subsequently, the Tertiary Education Fund of South Africa (TEFSA) was set up as a channel for financing disadvantaged students who were willing to improve themselves academically (RSA, 1999: 10). The implementation of the National Student Financial Aid Scheme Act (No 56 of 1999) was later launched, and Tfsa was mandated as an administrator for NSFAS (NSFAS, n.d.:1). 


\section{NSFAS changes past inequality in South Africa}

The introduction of the NSFAS Act aimed to rectify the inequality of the apartheid era; to tackle discrimination in higher education and/or to establish equal representation and react to human resources advancement in South Africa. The NSFAS was also implemented to be financially reasonable and sustainable(Letseka, Cosser, Breier \& Visser, 2010: 37).Thus, financial contributions came predominantly from the state which supplied approximately $78 \%$, while international sponsors contributed almost $18 \%$, tertiary institutions three percent and the private sector, one percent. In 2006, the Minister of Education Naledi Pandor distributed R1.3 billion in financial aid through NSFAS to help underprivileged students with other government bodies and private establishments, universities, and local and international foundations also raising R1.3 billion towards this aid. However, most years, the government adds a substantial amount of R250 million to the scheme in order that the NSFAS functions smoothly. About 38\% of this is allocated towards bad payments by students (Mc Gregor, 1995: 10).It is important to note that the NSFAS is a partial scheme merged with bursaries and loans. It must also be understood that along with this financial aid scheme it is vital that students contribute certain amounts as the resolution of a scheme is a difficult task (Mc Gregor, 1995: 10). Thus the NSFAS beneficiaries are responsible for transportation costs, accommodation, and food.

From 1993 to 1999 the number of black students benefiting from NSFAS has increased from 56\% to 73\%. This brought about a significant improvement in the racial profile and concerning the NSFAS's distribution of funds to higher education institutions within South Africa. Consequently, 400000 black students have benefited from NSFAS. (Letseka, et al., 2010: 38).However, even with an increase in the NSFAS's distribution of funds to higher education institutions a considerable number of students, for aiming to furthering their academic careers but been financially incapable of doing so, have been unable to access the NSFAS loans, due to the red tape involved. According to the Department of Education (DoE) in a study conducted by Letseka et al.(2010: 38) students who do not meet cut-off points set by the NSFAS and others pertaining to family income, will not be approved for a loan. This may demoralize potential students who may be deterred from applying for the NSFAS.

\section{Requirements to qualify for NSFAS}

The DoE (in Letseka, et al., 2010: 38) stipulates that the income of a student's family must fall below a set maximum, and that the sum of per capita income, set against the per capita maximum, acts as a cut-off point. If the family is unable to sustain both the applicants' tuition fees and the family's well-being, consideration in granting the loan to the applicant occurs. Further, the NSFAS bill (RSA, 1999: 12) stipulates that loans and bursaries from the NSFAS may only be approved for a specific discipline of study as indicated in the initial agreement. Within the contract signed by both the NSFAS and the beneficiary, a clause allows the board to be able to cease financing the student should he or she fail to meet certain standard set with regard to his or her studies. Subsequently, the NSFAS disburses funds to higher education institutions by means of allotment, according to the sum total owed by bursars to the institution.

\section{Presentation and analysis of quantitatively derived data}

The empirical data has been analyzed statistically through the use of frequency tables and graphical illustrations, which have been interpreted accordingly. Also included are samples of multivariate analysis which have been interpreted accordingly. It should be noted that the survey was built on the basis of a randomly selected sample of 83 current NSFAS beneficiaries.

\subsection{Univariate analysis of qualitatively derived data}

\section{Years of study}

In Figure 1 below, the graduate distribution of the respondents was highly disproportionate, with the majority (82; $98.2 \%)$ indicating they were undergraduates, with just one (1.2\%) postgraduate level. 
Figure 1: Pie Chart illustrating respondents`years of study

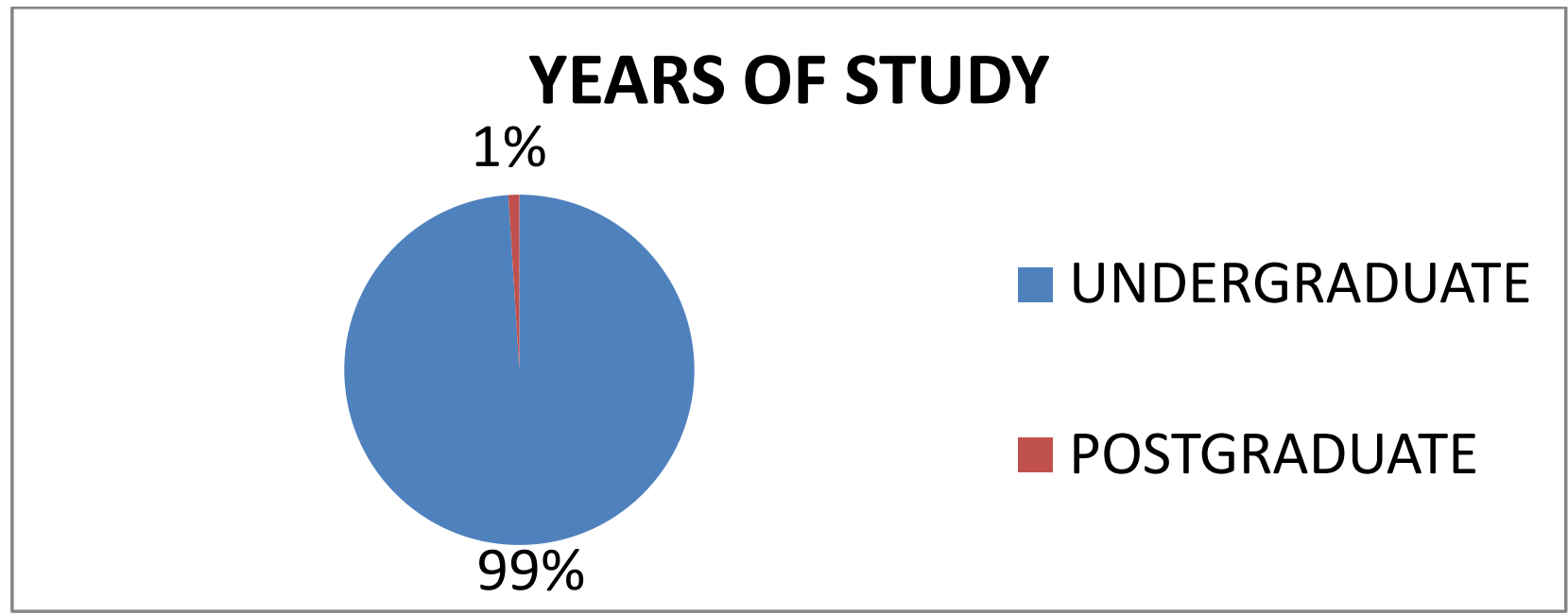

\section{First Language and ethnicity}

Only one respondent (1.2\%) indicated that their first language was English, while $42(50.6 \%)$ said it was Sotho/Tswana and two (2.4\%)stated that it was Afrikaans. Thirty seven respondents $(44.6 \%)$, however, indicated that Zulu/Xhosa was their first language and only one (1.2\%) spoke other languages. In Figure 2 below, it can be seen that a significant number of respondent $(80 ; 96.4 \%)$ stated that their ethnicity was African, with one $(1.2 \%)$ indicating and two $(2.4 \%)$ coloured ethnicity.

Figure 2: Bar graph illustrating the respondents` ethnicity

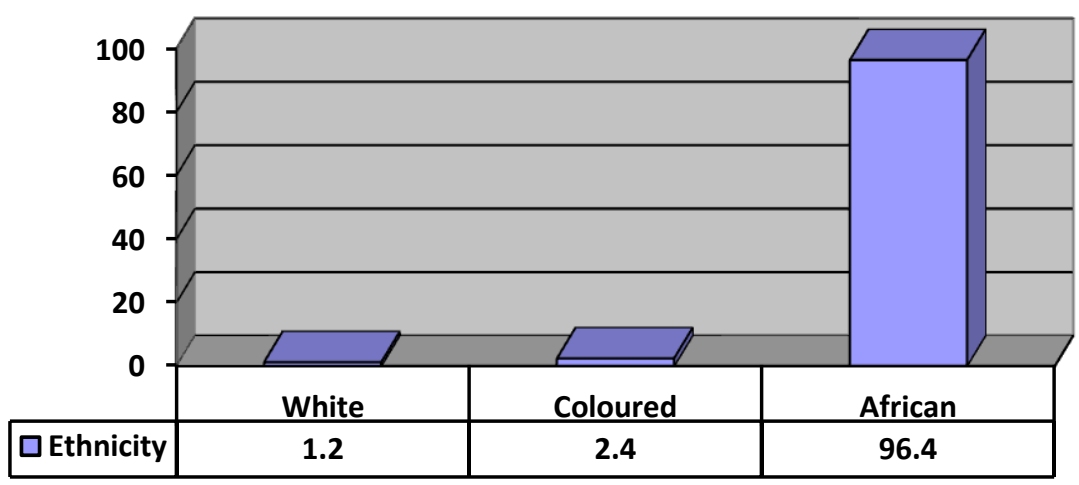

\section{Initial Awareness of NSFAS}

Figure 3: Colum chart illustrating the respondent's initial awareness of the NSFAS

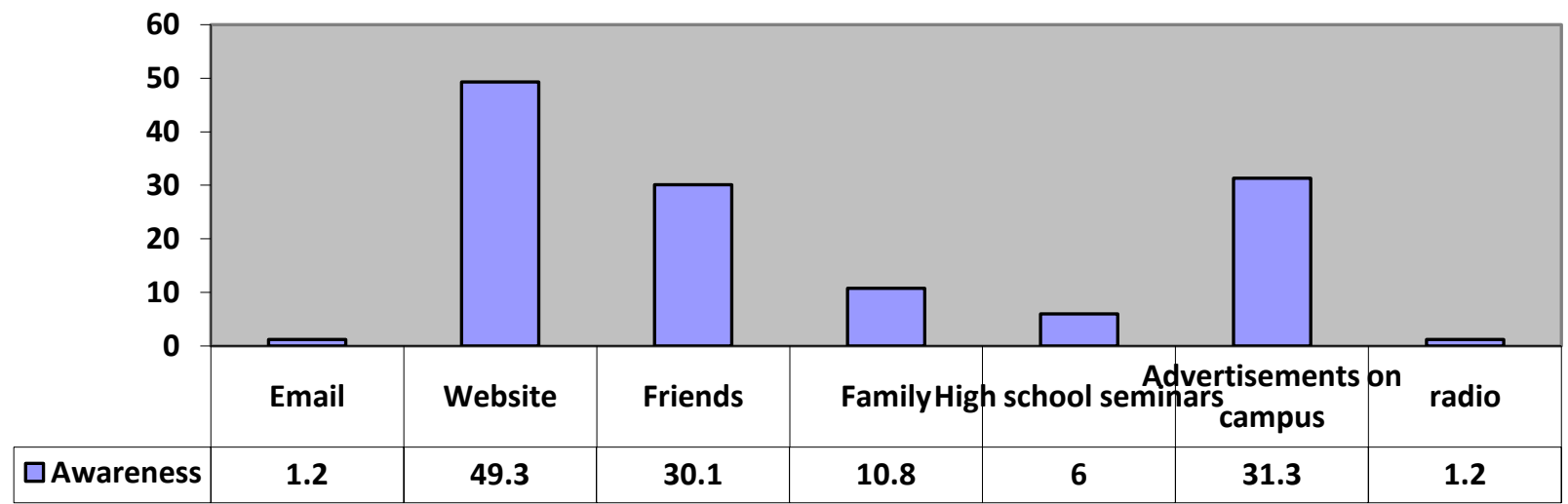


Figure 3 demonstrate that, of 83 respondents, 26 (31.3\%) indicated that they had become aware of the NSFAS through advertisements on campus, and another significant number, $(25 ; 30.1 \%)$ indicated that it was their friends who had told them about it. A further 16 respondents (19.3\%) indicated that their awareness came about after discovering the NSFAS website, while for nine (10.8\%), it was due to family members. Only five respondents $(6.0 \%)$ stated that they had first heard of the NSFAS during high school seminars and one (1.2\%) indicated awareness of the scheme through an email. Another respondent (1.2\%) stated that they learned about the NSFAS through the radio.

\section{Year(s) of NSFAS usage}

The following bar graph illustrates the number of years that the respondents have being utilizing the NSFAS:

Figure 4: Colum chart illustrating number of years the respondents has used the NSFAS

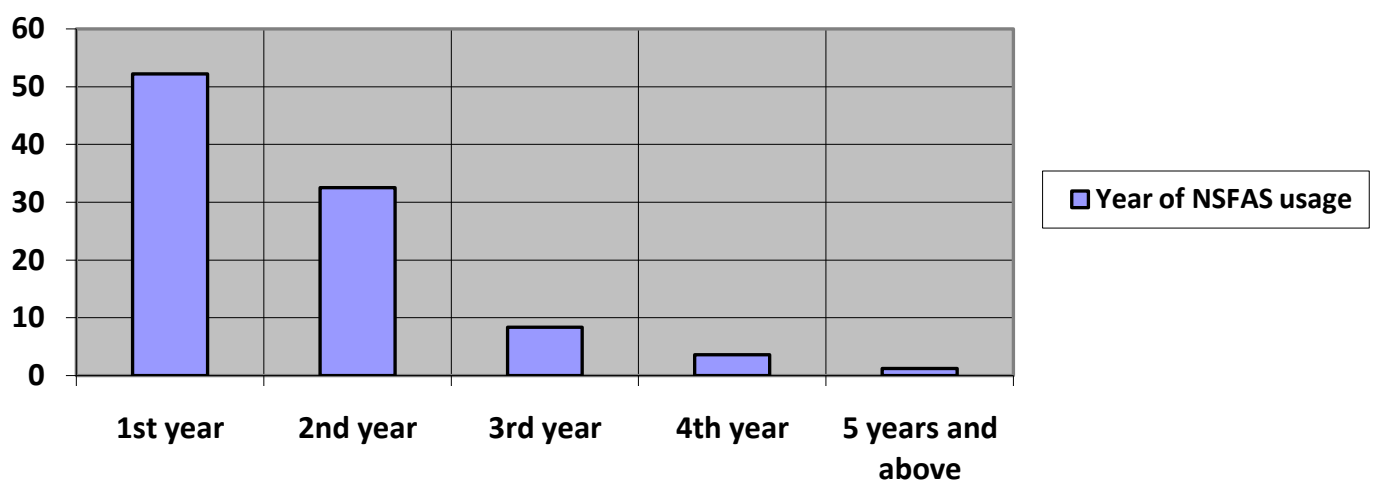

In Figure 4, 45 respondents $(52.2 \%)$ indicated that they had been making use of the NSFAS for a year, while 27 $(32.5 \%)$ had been doing so for two years. A smaller proportion of seven respondents $(8.4 \%)$ revealed that they had been utilizing it for three years, while three (3.6\%) said they had been using the scheme for four years. Only one $(1.2 \%)$ had been using it for five years or more.

Effort of application process and effort of document accessibility

Figure 5: Column chart illustrating the respondents' opinion about effort of the application process

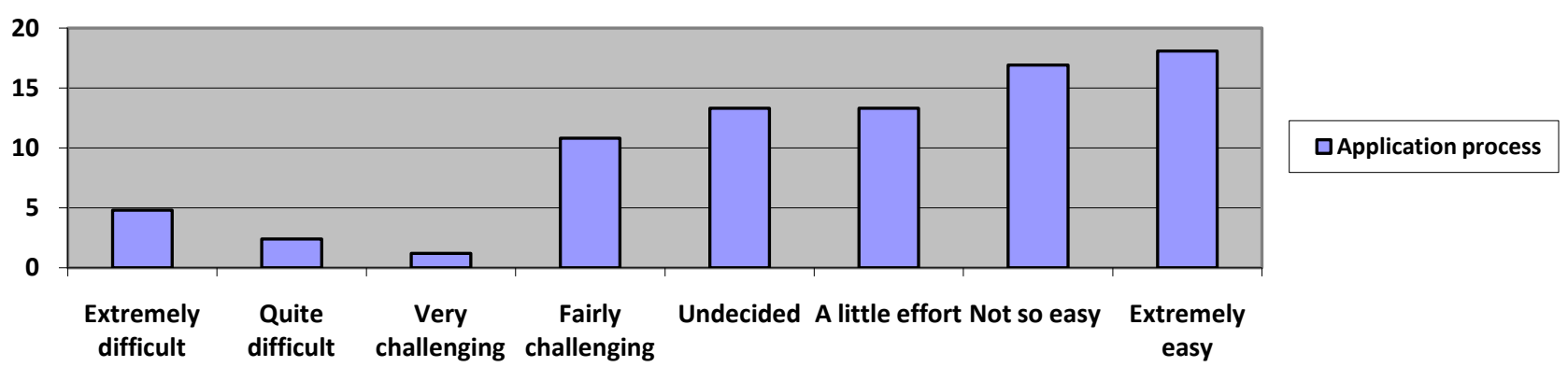

Firstly, in Figure 5, it can be deduced - that 15 respondents (18.1\%) indicated that the application process extremely easy, whereas 14 (16.9\%) stated that it was not easy. Eleven (13.3\%) specified that the application process had been achieved with a little effort, and 11 (13.3\%) stated that they were undecided about it. Nine respondents $(10.8 \%)$ answered that it had been a fairly challenging exercise, whereas two (2.4) stated that it had been difficult. Four respondents (4.8\%) indicated that they had found the process extremely difficult, with only one $(1.2 \%)$ specifying that they had found it very challenging.

Secondly, with regard to the effort made in accessing relevant documents for the NSFAS requirements, a greater number, namely, 23 respondents $(27.7 \%)$ indicated that it had been extremely easy. Another large proportion of respondents $15 ; 18.1 \%)$, however, had indicated that they had found the process to be not so easy. Eleven (13.3\%) stated that they had found access fairly easy, whereas four (4.8\%) indicated it had been extremely difficult. Seven $(8.4 \%)$ said that they were undecided, and while eight $(9.6 \%)$ revealed that they found document accessibility quite easy. 
Only one respondent $(1.2 \%)$ indicated that they found it quite difficult, while three $(3.6 \%)$ had found it quite challenging. Two of the respondents $(2.4 \%)$ also said that document accessibility had been fairly challenging, while nine $(10.8 \%)$ stated that it had taken a little effort.

\section{Effort of Application for Funding}

In Figure 6 below, the variable of financial advice indicated that 37 respondents (44.6\%)stated that the availability of financial advice was fairly easy to gain. However, 19(22.9\%) responses indicated indecision, while 14 (16.9\%) found the availability extremely easy. Only two (2.4\%) indicated that availability was extremely difficult. Eleven $(13.3 \%)$ responses indicated that the availability of financial advice had been challenging. In as far as the variable, "Gaining funding "is concerned, a total of 82 responses have been demonstrated, with one (1.2) response omitted. Of this total, 23 respondents $(27.7 \%)$ had stated that gaining funding from the NSFAS had been a fairly easy process, while 24(28.9\%) indicated that it had been extremely easy. However, 21(25.3\%) stated that gaining funding from the NSFAS had been challenging, while two (2.4\%) indicated extreme difficulty. Twelve (14.5\%) were undecided regarding this variable.

Figure 6: Column chart illustrating respondents' opinions of effort based on financial advice, gaining funding, and access to branch offices, and application for funding

\begin{tabular}{|l|c|c|c|c|}
\multicolumn{1}{|c|}{} & $\begin{array}{c}\text { financial } \\
\text { advice }\end{array}$ & $\begin{array}{c}\text { gaining } \\
\text { funding }\end{array}$ & $\begin{array}{c}\text { Access to } \\
\text { branch office }\end{array}$ & $\begin{array}{c}\text { Application } \\
\text { for funding }\end{array}$ \\
\hline$\square$ Extremely challenging & 2.4 & 2.4 & 1.2 & 0 \\
\hline$\square$ challenging & 13.3 & 25.3 & 13.3 & 13.3 \\
\hline$\square$ undicided & 22.9 & 14.5 & 27.7 & 10.8 \\
\hline$\square$ Fairly easy & 44.6 & 27.7 & 34.9 & 56.6 \\
\hline$\square$ Extremely easy & 16.9 & 28.9 & 22.9 & 19.3 \\
\hline$\square$ & & & & \\
\hline
\end{tabular}

The responses regarding the variable "Access to branch offices" illustrate that 29 respondents (34.9\%) found this fairly easy, with $19(22.9 \%)$ indicating it had been extremely easy. Eleven respondents (13.3\%) found accessibility challenging, and only one (1.2\%) indicated that it had been extremely difficult. In addition, 23 respondents $(27.7 \%)$ were undecided in this regard.

Finally, the variable "Application for funding"' reveals 83 responses, with 47 respondents $(56.6 \%)$ stating that they had found this process fairly easy. $16(19.3 \%)$ that it had been extremely easy, and $11(13.3 \%)$ indicating that it had been challenging. Only nine (10.8\%) indicated that they were undecided with regard to the application for funding.

\section{Response's to recommendations for the NSFAS and reasons why the NSFAS is recommended or not}

Sixty six respondents $(79.5 \%)$ indicated that their motivation for recommend the NSFAS was that it provided financial aid to needy students and that they would do so to both current and prospective students. A further 11 respondents $(13.3 \%)$ stated that the NSFAS provided financial peace of mind, while five $(6.0 \%)$ indicated that the scheme provided a low interest and allowed individuals to pay after finishing their studies and occurring a stable job. One respondent $(1.2 \%)$ stated that utilization of the scheme resulted in financial concerns after finishing with his or her studies. Thus, they would not recommend it. 


\section{Improvements on availability, accessibility, and marketing awareness of NSFAS}

Thirty six respondents (43.4\%) stated that they could recommend no improvements. However, 22 (26.5\%) indicated that the NSFAS could improve upon Secondary School Awareness. Only six (7.2\%) responses indicated that awareness could be improved through further advertisement on university campus. Three respondents (3.6\%) stated that branch offices should be made more readily available, and that the NSFAS should be more accessible to honors graduates. The later was supported by four respondents $(4.8 \%)$. Five $(6.0 \%)$ stated that current beneficiaries of the NSFAS should not need to reregister, to continue gaining funding from the financial aid scheme, if personal information remained unchanged each. Another five $(6.0 \%)$ responses indicated that the application time frame and funding should be extended. A further two (2.4\%) responses suggested that the NSFAS should also assist in financing transportation and accommodation for current or prospective beneficiaries.

\section{Bivariate analysis}

While interpreting the findings for this research, cross-tabulation were performed on several variables, in order to assess whether or not relationships existed between them. Cross-tabulation is a procedure that examines two variables, to determine whether their relationships are statistically significant. While few demonstrated a significance of $<0.005$, they did not stand up to the other two requirements of the Chi-square test, namely that there can be no empty cells, and that more than $20 \%$ of the cells cannot have a frequency of less than five. However, for the sake of academic purposes (ignoring the limitation of this exercise) a cross-tabulation is undertaken below.

Table1: The relationship between the numbers of years that respondents have been using the NSFAS and whether or not they found the application process difficult

\begin{tabular}{|l|l|l|l|l|l|l|l|}
\hline \multicolumn{2}{|l|}{ Number of years using NSFAS } \\
\hline Application Process & & $1^{\text {st }}$ Year & $2^{\text {nd }}$ Year & $3^{\text {rd }}$ Year & $4^{\text {th }}$ Year & $\begin{array}{l}5 \text { Years \& } \\
\text { Above }\end{array}$ & Total \\
\hline Extremely difficult & Count $\%$ & $0(0.0 \%)$ & $3(11.1 \%)$ & $1(14.3 \%)$ & $0(0.0 \%)$ & $0(0.0 \%)$ & $4(4.8 \%)$ \\
\hline Quite difficult & Count $\%$ & $1(2.2 \%)$ & $0(0.0 \%)$ & $1(14.3 \%)$ & $0(0.0 \%)$ & $0(0.0 \%)$ & $2(2.4 \%)$ \\
\hline $\begin{array}{l}\text { Relatively } \\
\text { challenging }\end{array}$ & Count \% & $0(0.0 \%)$ & $0(0.0 \%)$ & $1(14.3 \%)$ & $0(0.0 \%)$ & $0(0.0 \%)$ & $1(1.2 \%)$ \\
\hline Fairly challenging & Count \% & $2(4.4 \%)$ & $2(7.4 \%)$ & $0(0.0 \%)$ & $1(33.3 \%)$ & $1(100 \%)$ & $6(7.2 \%)$ \\
\hline Uncertain & Count \% & $5((11.1 \%)$ & $5(18.5 \%)$ & $0(0.0 \%)$ & $1(33.3 \%)$ & $0(0.0 \%)$ & $11(13.3 \%)$ \\
\hline A little effort & Count \% & $9(20.0 \%)$ & $0(0.0 \%)$ & $1(14.3 \%)$ & $0(0.0 \%)$ & $0(0.0 \%)$ & $10(12.0 \%)$ \\
\hline Not so Easy & Count \% & $6(13.3 \%)$ & $7(25.9 \%)$ & $0(0.0 \%)$ & $1(33.3 \%)$ & $0(0.0 \%)$ & $14(16.9 \%)$ \\
\hline Fairly easy & Count \% & $7(15.6 \%)$ & $0(0.0 \%)$ & $2(28.6 \%)$ & $0(0.0 \%)$ & $0(0.0 \%)$ & $9(10.8 \%)$ \\
\hline Quite easy & Count \% & $6(13.3 \%)$ & $4(14.8 \%)$ & $\mathrm{I}(14.3 \%)$ & $0(0.0 \%)$ & $0(0.0 \%)$ & $\mathrm{II}(13.3 \%)$ \\
\hline Extremely easy & Count $\%$ & $9(20.0 \%)$ & $6(22.2 \%)$ & $0(0.0 \%)$ & $0(0.0 \%)$ & $0(0.0 \%)$ & $15(18.1 \%)$ \\
\hline Total & Count \% & $45(100 \%)$ & $27(100 \%)$ & $7(100 \%)$ & $3(100 \%)$ & $1(100 \%)$ & $83(100 \%)$ \\
\hline
\end{tabular}
a)
$\mathrm{N}=83$,
b) $\mathrm{x}=2$,
c) $d=36$,
d) $\mathrm{p}=0.009$

Of the students who found the application process extremely difficult, $11.1 \%$ were second year and $14.3 \%$ were third year scholars. Thus those in their second and third years were more likely to find it extremely challenging. It is interesting to note that no first year student found this extremely challenging. Rather, $20.0 \%$ of the respondents who indicated that they were first year scholars found the application process extremely easy. The reason for this may be because they may receive more institutional help in filling out forms than second and third year scholars, as it assumed that the former not know how to do so. This demonstrates that proportion of second and third year students still need assistance in this regard.

While analyzing the results, however we were surprised to find that of the relationship we expected to be contingent, none were relevant in accordance to the Chi-Square Test. For instance, we expected there to be a relationship between the application process and the respondent's languages. However, the significant indicated $p$ $=0.735$ thus voiding this contingent. Furthermore, a cross-tabulation that we expected to be relevant was the relationship between gaining funding from the NSFAS and the respondents' ethnicity. However, the significance here also indicated $\mathrm{p}=0.900$. We had also hoped to find a correlation between accessibility of offices and access to financial advice. However, the Chi-Square Test indicated that $\mathrm{p}=0.390$ thus, disproving any relationship between these two variables. 


\section{Recommendations}

Out of the 83 respondents, the large majority of the beneficiaries are undergraduates $(98.8 \%)$, with only one $(1.2 \%)$ a postgraduate student (refer to Figure 1.).Four respondents $(4.8 \%)$ recommended that the NSFAS should be more readily available to postgraduate students. These findings suggest that the scheme mainly caters for undergraduates, which unfortunately may not benefit those who wish to further their studies. Figure.2. revealed that, respondents who make use of the scheme are predominantly Tswana/Sotho (50.6\%) and Zulu/Xhosa (44.6\%) speaking. This coincides with the results demonstrated in Figure.3, which illustrates the samples of awareness of the NSFAS. Of the 83 respondents in this survey, the large majority are African (96.4\%), which can be further supported by the latest statistics provided by the NSFAS on their official website which indicates that $93 \%$ of their beneficiaries are African (NSFAS, n.d.:1).

Furthermore, eighty two respondents that stated that they would recommend the NSFAS to current or prospective students, due to the fact that it provides financial aid to needy students. These results are supported by the literature survey, which indicates the essential role that the scheme plays in assisting financially disadvantaged individuals.

Figure 6 reveals that a large portion of the respondents indicated that access to financial advice, gaining funds, access to branch offices and application for funding had been fairly easy. This was affirmed by 37 respondents (44.6\%) in terms of financial advice, $23(27.7 \%)$ with regard to gaining funding, 29 (34.9\%) in terms of accessibility to the NSFAS's branch offices, and finally, by $47(56.6 \%)$ with regard to application for funding. In light of these responses, there is sufficient evidence to conclude that the administration of the NSFAS is considerably well organized. However, it is also important to note that 21 respondents (25.3\%) (refer to Figure 8) indicated that gaining funding through the NSFAS was challenging, which in turn signified restrictions the scheme had with regards to availability of funds.

Results from document accessibility (see Figure 6) and application process (Figure.5) indicated that the respondents generally found the process relatively easy. This was supported by the results from the sample. Firstly, at Figure 5, 15 respondents (18.1\%) indicated that the application process had been extremely easy, followed by 11 respondents $(13.3 \%)$ who perceived that it had been to be quite difficult. With regard to document accessibility in Figure 6, 23 respondents (27.7\%) considered that it had been fairly easy, compared to four (4.8\%) who said they found it extremely difficult. Although a few respondents had found the process difficult, a larger proportion had stated otherwise, which could indicate that both variables are realistically achievable without too much effort.

Among the recommendations for improving availability, accessibility and marketing awareness of the NSFAS (see Figure $3 \& 6$ ), 22respondents (26.5\%) recommended that the scheme should improve upon Secondary School Awareness of the NSFAS funding available, and that it might offer individuals who previously believed they had no future, the opportunity to improve their lives" (respondent 47). A further six respondents (7.2\%) opined that the NSFAS should advertise their financial aid with great frequency on university campuses. Two respondents $(2.4 \%)$ recommended that the scheme should also provide financial assistance with transportation, accommodation, and entertainment. Thus, it is important to consider; as the students who benefit from this financial aid are needy, that perhaps aid in these fields may also be necessary in terms of NSFAS beneficiaries succeeding at completing their tertiary education.

\section{Limitations and recommendations for future research}

The numbers of respondents in the sample were small and this may not truly represent the views of the NSFAS beneficiaries at other universities. Thus, it is recommended that a larger sample frame be employed to ensure that the results are representative. A limited time frame in which the researchers had to conduct and report the findings emerged as a limitation. Thus, it is recommended that more time be allocated to any future quantitative research in this regard. Furthermore, it is suggested that the questionnaire be adapted, as due to its format, it was found that cross-tabulations and significant contingents had been difficult to accumulate.

\section{Conclusion}

The NSFAS is regarded as an important means of leverage into higher educational institutions. It provides needy individuals with the opportunity to better themselves and improve upon their chances in the future. This study attempted; through a selection of current beneficiaries of the NSFAS at NWU, to ascertain opinions, expectations 
and needs and represent them appropriately. Through this assessment, the researchers were able to determine that the administrative sector within the NSFAS was, on the whole, well organized, and that access to the scheme was fairly easy. However, a number of respondents recommended that the NSFAS be advertised at high schools and made more readily available to both undergraduate and postgraduate students.

\section{References}

Barr, N. (1993). Alternative Funding Resources for Higher Education. Blackwell Publishers, UK.. Retrieved from: http://www.jstor.org/stable/2234544?seq=1- on April 2011.

Ben-Tsur, D. (2007). Affairs of state and student retention: An exploratory study of the factors that impact student retention in a politically turbulent region. British Journal of Sociology of Education, 28 (2), 317 - 332.

Bhorat, M., Leibbrandt, M., Maziya, M., Van Der Berg, S., \& Woolard, I. (2001).Fighting Poverty: Labor Markets and Inequality in South Africa. University of Cape Town Press, South Africa.

Bhorat, H., \& Van der Westhuizen, C. (2009). Economic Growth, Poverty and Inequality in South Africa: The First Decade of Democracy. University of Cape Town, South Africa.

Booij, A.S., Leuven, E., \& Oosterbeek, H. (2011).The role of information in the take-up of student loans. Economics of Education Review, August, 1- 2.

Breier, M. (2010). From financial considerations to Poverty: Towards a Reconceptualization of the Role of finances in higher education student drop out. The International journal of Higher Education and Educational Planning, 60 (6), 657.

Carter, M.R., \& May, J. (1999).One kind of freedom: Poverty dynamics in post-apartheid South Africa. World Development 29 (12), 24.

Chapman, B. \& Lounkaew, K. (2010) Thailand's students' loan fund: Interest rate subsidies and payment burden. Economics of Education Review, 29, 685-694.

Cohen, L., Manion, L. \& Morison, K. (2007). Research Methods in Education $6^{\text {th }}$ ed.).London: Routledge: London.

De Villiers, P. (2009). The cost of fiscal subsidies to higher education students in South Africa: A comparison between 2000 and 2006. Stellenbosch Economic Working Papers 13 (9), 4-5. Retrieved from: http://www.ekon.sun.ac.za/wpapers/2009/wp132009/wp-13-2009.pdf10March2011.

De Villiers, P., \& Steyn, G.(2006). Income and expenditure trends of higher education institutions in South Africa. Journal of Perspective in Education. 24 (2), $35-48$.

Goetz, J.W., Miti. Y.M., Desai, P., \& Cude, B.J. (2008) HOPE or No-HOPE: Merit-Based College Scholarship: Status and Financial Behaviors Among College Students. Georgia: Association for Financial Counseling and Planning Education. Georgia.

multilevel analysis. International Journal of Education Development, December, 560-562.Hoogeveen, J.G. \& Ozler, B. (2005) Not Separate, Not Equal: Poverty and Inequality in Post-Apartheid South Africa. The William Davidson Institute at the University of Michigan Business School. USA. Retrieved from :http://deepblue.lib.umich.edu/bitstream/2007.42/40125/3/wp739.pdf2 May2011.

Kerkvliet, J., \& Nowell, C. (2005) Does one size fit all? University differences in the influence of wages, financial aid, and integration on student retention. Economic of Education Review, March, 85-86.

Koen, C., Cele, M., \& Libhaber, A. (2006) Student activism and student exclusions in South Africa. International Journal of Educational Development, September, 404-406.

Letseka, M., Cosser, M., Breier, M., \& Visser, M. (2010). Student Retention and Gruduate Destination: Higher Education and Labour Market Access and Success. Human Science Research Council- Press. Cape Town.

Mc- Gregor, K. (1995). Student aid scheme creaks into action. Times Higher Education Supplement.1 (1201), 5-8.

Mare, K. ed. (2007) First steps in research. Van Schaik Publishers. Pretoria.

Marks G.N. (2009). The social effects of the Australian Higher Education Contribution Scheme (HECS). Higher Education 57 (1), $71-84$.

NSFAS: National Student Financial Aid Scheme. (n.d). Retrieved from: http://www.nsfas.org.z a/index.htm17March2011.

National Student Financial Aid Scheme Bill. (1999). (c. 75). Minister of Education. Republic of South Africa.

Salmi, J. (2003). Student Loans in an International Perspective: The World Bank Experience. Paper presented to World Bank's Annual Bank Conference, January, 1-5. Retrieved from:

http://www.info.worldbank. org/etools/docs/library/250794/session6StudentinInternationalSalmi.pdf2 May 2011.

Singell, L.D. (2002). Merit, need and student self-selection: is there discretion in the packaging of aid at a large public university? Economics of Education Review, March, 445-446.

Teferra, D., \& Knight, J. (2008). Higher Education in Africa: The International Dimension. Boston College Center for International Higher Education, Washington.

Thomas, L., Cooper, M., \& Quinn, J. ed. (2003) Improving Completion Rates Among Disadvantaged Students. Trentham Books, Wiltshire, UK. .

Waddell, G.R., \& Singell, L.D. (2011). Do no-loan policies change the matriculation pattern of low income students? Economics of Education Review, October, 203-214.

Woodhall, M. (1989). Financial Support for Students: Institute of Education. University of London, London.

Williams, G. (1992). Changing Patterns of Finance in Higher Education. Open University Press and SRHE, London.

Yang, P. (2010). Who gets more financial aid in China? A

Zeleza, P.T., \& Olukoshi, A. (2004). African Universities in the twenty-first century. CODERSRIA Senegal. 